\title{
$\mathrm{u}$-주거공간의 $\mathrm{u}$-서비스 추출 방법론 및 적용에 관한 연구 \\ 이행우* · 정진성** · 김용성***
}

\section{A Study on the u-Residential Space Service: Focusing on u-Service Extraction and Application}

\author{
Heang-Woo Lee* $\cdot$ Jin-Sung, Jung** $\cdot$ Yong-Seong Kim***
}

\begin{abstract}
The u-City construction plan being executed presently involves such problem that services are provided in a suppliers-oriented direction while there are not much discussions on what u-Services citizens should be provided with and what $u$-Services that city government the supplier shall provide.

In order to implement citizen-friendly u-Services the type of u-Services that offer just the right services efficient and convenient for citizens, u-Services should be provided based on active researches on the citizens' use and utilization of u-Services rather than u-Services being provided in suppliers' perspective as so far. To that end, there need be recognition and well-organized methodology that u-Services should be provided through humane, social and scientific analysis of the citizens that are to be provided with u-Services.

Thus, in this study, the process of u-Services being transmitted was re-interpreted as background theory to deduce and apply services appropriate for u-Residential Space, and service science for u-Services the scientific and overall approach to seek for service innovation was applied to the development of $u$-Service deduction method based on such background theory. The u-Service methodology developed based on service science is judged able to deduce and provide u-Services appropriate for the intended services through scientific analysis of citizen-friendly u-Services.

Keyword : u-Service, u-Residence Space, Service Science
\end{abstract}

\footnotetext{
논문투고일 : 2011년 07월 21일 논문수정완료일 : 2011년 09월 14일 논문게재확정일 : 2011년 09월 21일 * 국민대학교 테크노디자인전문대학원, 박사과정

** 국민대학교 테크노디자인전문대학원, 석사과정

*** 국민대학교 테크노디자인전문대학원 교수
} 


\section{1. 서 론}

\section{1 연구의 배경 및 목적}

정보기술이 발달하면서 유비쿼터스 환경은 보이 지 않는 서비스로서 도시환경의 도처에 이미 존재 하거나 만들어지고 있다. 또한, 유비쿼터스는 정부 가 국가경제 활성화, 국가경쟁력 향상, 군민의 삶 의 질 향상이라는 국가 발전 전략으로 ' $\mathrm{u}$-Korea' 를 제시할 만큼 시대적인 패러다임으로서 자리매 김하고 있다. 이러한 상황에서 각 지자체 단체들 은 경쟁적으로 $\mathrm{u}-\mathrm{City}$ 건설을 추진하여 시민의 삶의 질 향상이라는 이름으로 다양한 $\mathrm{u}$-서비스를 제공하고 있다. 그러나 현재 추진되고 있는 u-City 건설계획은 실제 서비스를 이용하는 시민들을 대 상으로 한 $\mathrm{u}^{-}$서비스보다 공급자 위주의 $\mathrm{u}^{-}$서비스 제공이 이루어져 실제 $\mathrm{u}^{-}$서비스의 제공에 있어서 서비스의 적합성과 활용도가 문제점으로 파악된 다[5].

이러한 상황에서 시민들이 $\mathrm{u}^{-}$서비스를 효율적이 고 편리하게 사용할 수 있으며, 적합한 $\mathrm{u}^{-}$서비스의 제공을 이루기 위해서는 공급자 위주의 서비스제 공이 아닌 시민들을 위한 $\mathrm{u}^{-}$서비스 제공에 대한 이 해와 연구를 바탕으로 $\mathrm{u}^{-}$서비스가 제안되어야 할 것이다. 또한, $\mathrm{u}^{-}$서비스의 공급을 대상 시민과 대 상 장소에 대한 인문적, 과학적, 사회적 분석을 통 하여 $\mathrm{u}^{-}$서비스의 제공이 이루어져야 한다는 인식 과 이에 대한 체계적인 방법론의 필요성이 요청되 고 있다.

본 연구는 현재 추진되고 있는 $\mathrm{u}-\mathrm{City}$ 의 가장 큰 문제점인 사용자 측면에 입각한 $\mathrm{u}^{-}$서비스의 효 율성과 타당성, 적합성에 대한 문제를 해결하기 위한 방안으로서 $\mathrm{u}^{-}$서비스 방법론을 제안하고, 이 를 통하여 $\mathrm{u}-\mathrm{City}$ 내에서 시민들에가 가장 근접한 도시공간인 $\mathrm{u}^{-}$주거공간에 적합한 $\mathrm{u}^{-}$서비스를 추 출하고, $\mathrm{u}^{-}$서비스 적용 시 $\mathrm{u}^{-}$서비스 추출방법으로 활용하는 것을 목적으로 한다.

\section{2 연구의 범위 및 방법}

본 연구에서는 서비스 혁신을 도모하는 과학적이 고 종합적인 접근방법인 서비스사이언스를 기본이 론으로 관련 기법을 활용하여 $\mathrm{u}^{-}$서비스 추출 방법 론을 제시하고, 국토해양부 $\mathrm{u}-\mathrm{Eco}$ City 사업단의 228 개 단위서비스를 기반으로 하여 주거 공간에 적 합한 $\mathrm{u}^{-}$서비스를 도출하였다. $\mathrm{u}-\mathrm{Eco}$ City 사업단 의 228 개 단위서비스는 r유비쿼터스도시의 건설 등에 관한 법률」제 2 조 제 2 호에서 명기한 11 개의 분야에 대한 228 개의 $\mathrm{u}-$ 서비스를 세부적으로 묘사 하고 있으며 실제적으로 추진되고 있어서 도출을 위한 대상으로 적합하다고 판단되며, $\mathrm{u}$-주거공간 에 적합한 서비스를 도출하기 위하여 [그림 1]과 같은 절차에 의하여 진행하였다.

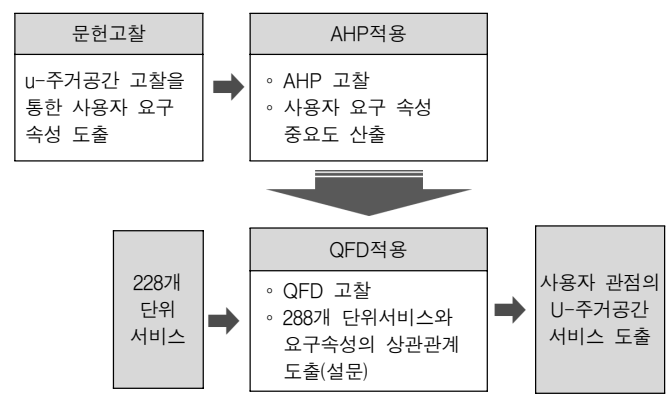

[그림 1] 연구의 흐름도

첫째, 아직 구체화되지 않은 $\mathrm{u}$-주거공간 사용자 의 니즈(needs) 인식 및 수요를 예측하기 위하여 선행연구사례의 $\mathrm{u}^{-}$서비스 수요조사를 활용하였으 며, $\mathrm{u}$-주거공간 사용자의 일반적인 요구속성을 도 출하고 이를 $\mathrm{AHP}$ (Analytic Hierarchy Process, 다 수 대안에 대하여 다면적 평가기준을 바탕으로 한 의사결정방법)기법을 통하여 $\mathrm{u}$-주거공간 사용자 의 요구속성 중요도로 환산한다.

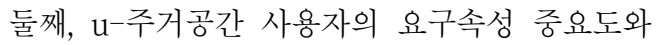
$\mathrm{u}$-주거공간 서비스의 상관관계를 $\mathrm{QFD}$ (Quality Function Deployment, 고객의 다양한 needs로부 터 연구, 개발, 요소기술, 제조, 및 물류 단계 등 회 
사의 업무 요구사항으로 전환하는 체계적인 접근 방법을 지칭)를 통하여 분석하고 그 결과 값인 $\mathrm{u}^{-}$ 주거공간 서비스의 우선순위를 바탕으로 적합한 서비스를 도출한다.

추가적으로, $\mathrm{AHP}$ 와 $\mathrm{QFD}$ 의 적용과정에서는 복 잡한 계산식과 분석과정이 필요하므로 정확도와 활용의 용이성을 위하여, 각각 기법의 활용이 가 능하도록 제공되고 있는 툴을 사용하였다.

\section{2. $\mathrm{u}^{-}$주거공간 $\mathrm{u}$-서비스에 관한 고찰}

\section{1 u-City 및 u-City 서비스의 문제점}

u-City 계획 핵심은 $\mathrm{u}-$ City Technology를 기반 으로 $\mathrm{u}$-City 내에 어떠한 서비스를 제공할 것인가 가 그 핵심이다.

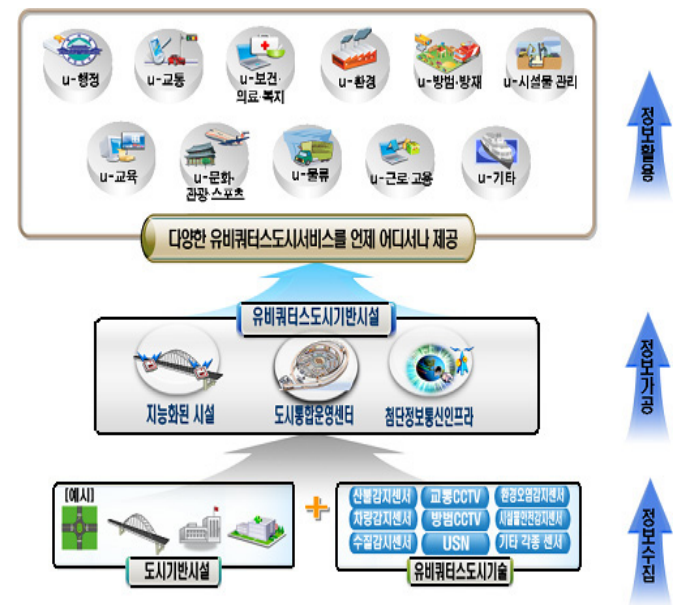

[그림 2] u-City의 개념

그러나 일반적인 $\mathrm{u}-\mathrm{City}$ 의 정의는 [그림 2]에서 나타나듯 개념이 방대하고 모호한 특성을 지니고 있으며, 각 기관 및 단체별로 도시의 전 분야에 걸 쳐 768개, 228개 등 그 범위와 제공방법이 목록 나 열의 차원에서 방대하고 모호하게 설정되어 결국 실제 서비스의 사용자와 대상이 고려되지 않은 상
태에서 공급이 가능한 기술에 대한 서비스들을 목 록화 함으로써 $\mathrm{u}^{-}$서비스 공급의 측면만 부각되고 있다. 이러한 방대한 양의 서비스를 사용자와 대 상에 대한 분석을 바탕으로 한 판단기준 없이 실 제 u-City 계획에 적용하는 것은 현실적으로 불가 능하며, 소모적인 서비스 제공이 이루어질 가능성 이 높다. 이에 따라 현재 상황처럼 공급자 위주의 서비스제공이 아닌 적극적으로 사용자들의 $\mathrm{u}^{-}$서 비스 이용 및 활용에 대한 연구를 바탕으로 한 $\mathrm{u}^{-}$ 서비스의 제공이 이루어져야 한다는 인식이 증가 하고 있으며, 이에 대한 해결책으로서 체계적인 방법론의 필요성이 대두되고 있다.

\section{$2.2 \mathrm{U}$-주거공간의 정의}

본 연구에서 $\mathrm{u}^{-}$서비스의 대상으로 지정한 $\mathrm{u}^{-}$주 거공간에 대하여 [그림 3]에서 나타나듯 $\mathrm{u}^{-}$주거공 간은 편리, 안전, 쾌적한 도시 비전을 실현하기 위해 기존의 주거공간 및 주거단지에 유비쿼터스 기술 을 융합시킨 새로운 상징공간으로 가정공간(Home 서비스), 도시 내 생활, 교육, 복지, 문화 등의 복합 적 의미를 내포하는 소 생활권 단지기반 서비스 (School Zone 서비스) 및 안전관리서비스(Playground 서비스)등이 제공되는 공간이라 정의 된다.

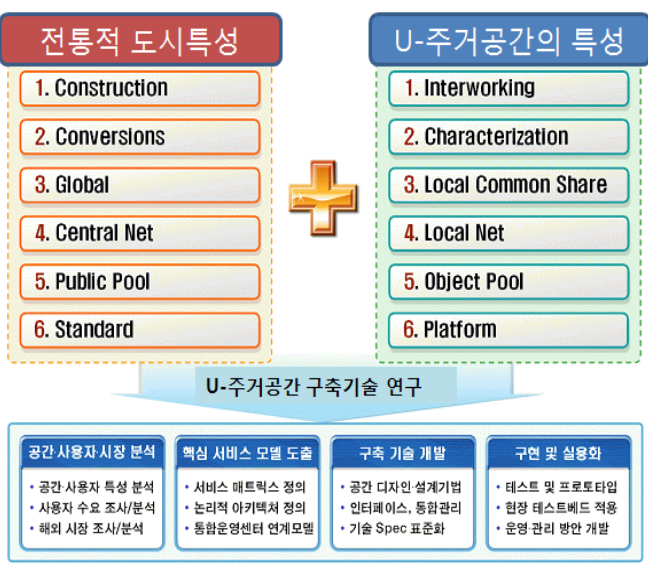

[그림 3] u-주거공간의 특성에 따른 핵심기술의 정의 


\section{3 u-City 및 $\mathrm{u}$-주거공간의 서비스}

현재까지 $\mathrm{u}-\mathrm{City}$ 를 위한 주거공간에 대한 $\mathrm{u}^{-}$서 비스는 기본적으로 $\mathrm{u}-\mathrm{City}$ 사업에 포함되어 왔으 나, $\mathrm{u}$-주거공간을 구축함에 있어서 사용자인 도시 민과 각각의 공간 자체에 대한 요구사항 및 특성 이 심도 깊게 분석되지 않았으며, 시민친화적인 유 비쿼터스 서비스를 구현하기 위한 특화된 건설기술 및 $\mathrm{u}-\mathrm{IT}$ 기술에 대한 상세 분석도 부족하여, 기존 의 도시 모델과 차별화가 부족할 뿐만 아니라 실 제 구현 및 활용에 어려움을 겪는 서비스가 많다.

다음 <표 1>은 본 연구에서 기반으로 하고 있 는 국토해양부의 228 개 단위서비스 목록을 정리한 것이다.

〈표 1〉u-Eco City 사업단의 228개 단위서비스

\begin{tabular}{|c|c|c|}
\hline 분야 & 통합서비스명 & 단위서비스 항목 \\
\hline \multirow{5}{*}{ 행정 } & 현장행정지원 & $\begin{array}{l}\text { 불법쓰레기투기감시서비스 외 2개 } \\
\text { 항목 }\end{array}$ \\
\hline & 도시경관관리 & $\mathrm{u}^{-}$플래카드서비스 외 3개 항목 \\
\hline & 원격민원행정 & $\mathrm{u}$-민원서비스 외 1개 항목 \\
\hline & 생활편의 & $\mathrm{u}^{-}$이사서비스 외 2 개 항목 \\
\hline & 시민참여 & 시민신고서비스 외 2개 항목 \\
\hline \multirow{7}{*}{ 교통 } & 교통관리최적화 & 실시간교통제어서비스 외 15 개 항목 \\
\hline & 전자지불처리 & 주차요금전자지불서비스 외 3개 항목 \\
\hline & 교통정보유통활성화 & 기본교통정보제공서비스 외 1 개 항목 \\
\hline & 차량여행자정보제공 & 보행자경로제공서비스 외 1개 항목 \\
\hline & 대중교통 & 대중교통정보제공서비스 외 1개 항목 \\
\hline & 차량도로첨단화 & 보행자안전지원서비스 외 12 개 항목 \\
\hline & 택시콜 & 택시콜서비스 \\
\hline \multirow{9}{*}{$\begin{array}{l}\text { 보건 - } \\
\text { 의료 - } \\
\text { 복지 }\end{array}$} & 건강관리서비스 & 홈건강관리서비스 외 3 개 항목 \\
\hline & U-병원서비스 & 병원정보화서비스 외 5 개 항목 \\
\hline & 원격의료서비스 & 원격진료서비스 외 3 개 항목 \\
\hline & U-보건관리서비스 & 개인건강정보관리서비스 외 3개 항목 \\
\hline & U-보건소서비스 & 보건소종합정보서비스 외 1개 항목 \\
\hline & 가족안심서비스 & $\begin{array}{l}\text { 치매노인/미아방지서비스 외 3개 } \\
\text { 항목 }\end{array}$ \\
\hline & 장애인지원서비스 & 장애인보행지원서비스 외 1 개 항목 \\
\hline & 다문화가정지원 & 다문화가정도우미서비스 \\
\hline & 출산 및 보육지원 & 출산및보육지원서비스 \\
\hline \multirow{5}{*}{ 환경 } & 오염관리서비스 & 수자원오염관리서비스 외 3 개 항목 \\
\hline & 폐기물관리서비스 & 생활쓰레기관리서비스 외 3 개 항목 \\
\hline & 친환경서비스 & 생태공간관리서비스 외 3 개 항목 \\
\hline & 에너지효율화서비스 & 에너지원격검침서비스 외 2 개 항목 \\
\hline & 신·재생에너지서비스 & 태양광발전서비스 외 3 개 항목 \\
\hline
\end{tabular}

\begin{tabular}{|c|c|c|}
\hline \multirow{8}{*}{$\begin{array}{l}\text { 방범- } \\
\text { 방재 }\end{array}$} & 구조구급 & 위급알림서비스 외 1 개 항목 \\
\hline & 개인안심 & 가정방범방재서비스 외 1 개 항목 \\
\hline & 공공안전 & 공공지역안전감시서비스 외 3개 항목 \\
\hline & 기관안전 & 무인경비서비스 \\
\hline & 화재관리 & u-화재감지서비스 외 2개 항목 \\
\hline & 자연재해관리 & 하천범람정보서비스 외 4개 항목 \\
\hline & 사고관리 & 노후건물상태관리서비스 외 2개 항목 \\
\hline & 통합재해관리 & 통합재해관리서비스 \\
\hline \multirow{6}{*}{$\begin{array}{l}\text { 시설물 } \\
\text { 관리 }\end{array}$} & 도로시설물관리 & 교통시설물관리서비스 외 3 개 항목 \\
\hline & 건물관리서비스 & 건물관리서비스 \\
\hline & 하천시설물관리 & 하천시설물관리서비스 \\
\hline & 부대시설물관리 & 옹벽안전관리서비스 외 1 개 항목 \\
\hline & 지하공급시설물관리 & 공동구관리서비스 외 2개 항목 \\
\hline & 데이터관리 및 제공 & 도면협업관리서비스 외 2 개 항목 \\
\hline \multirow{6}{*}{ 교육 } & U-유치원서비스 & $\begin{array}{l}\text { 실시간보육현황조회서비스 외 } 1 \text { 개 } \\
\text { 항목 }\end{array}$ \\
\hline & U-캠퍼스서비스 & 캠퍼스종합정보서비스 외 5 개 항목 \\
\hline & U-교실서비스 & $\mathrm{u}$-교실서비스 \\
\hline & 원격교육서비스 & 온라인교육서비스 \\
\hline & U-도서관서비스 & $\mathrm{u}$-서고서비스 외 4 개 항목 \\
\hline & 장애인학습지원 & 장애인학습지원서비스 \\
\hline \multirow{8}{*}{$\begin{array}{l}\text { 문화 · } \\
\text { 관광 . } \\
\text { 프포츠 }\end{array}$} & 문화시설관리 & 문화재보존관리서비스 외 1개 항목 \\
\hline & 문화공간체험 & $\mathrm{u}$-전시관 서비스 \\
\hline & 문화정보안내 & 문화정보종합안내서비스 \\
\hline & U-관광정보안내 & $\mathrm{u}$-투어서비스 외 4 개 항목 \\
\hline & $\mathrm{U}$-공원 & 공원정보안내서비스 \\
\hline & U-놀이터 & u-놀이터서비스 \\
\hline & U-리조트 & $\mathrm{u}^{\text {-리조트서비스 }}$ \\
\hline & $\mathrm{U}$-스포츠 & $\mathrm{u}$-생활체육서비스 외 2 개 항목 \\
\hline \multirow{7}{*}{ 물류 } & 생산이력추적관리 & u-Factory 외 3 개 항목 \\
\hline & U-물류센터 & 지능형피킹/패킹서비스 외 2개 항목 \\
\hline & U-운송 & 최적운송경로안내서비스 외 3개 항목 \\
\hline & U-배송 & 무인우편/택배서비스 \\
\hline & 유통이력추적조회 & 제품이력추적서비스 외 1 개 항목 \\
\hline & U-매장 & 지능형매장관리서비스 외 1개 항목 \\
\hline & U-쇼핑 & $\begin{array}{l}\text { 개인맞춤형쇼핑정보서비스 외 3개 } \\
\text { 항목 }\end{array}$ \\
\hline \multirow{4}{*}{$\begin{array}{l}\text { 근로 } \\
\text { 고용 }\end{array}$} & 고용정보서비스 & 고용동향정보서비스 외 4개 항목 \\
\hline & U-Work서비스 & 원격협업서비스 외 6개 항목 \\
\hline & 산업활동지원 & 창업지원서비스 외 2 개 항목 \\
\hline & 산업안전관리 & 위험업무원격지원서비스 외 1 개 항목 \\
\hline \multirow{5}{*}{ 기타 } & 홈매니지먼트서비스 & 홈오토메이션서비스 외 1개 항목 \\
\hline & 외부연계서비스 & 주차장연동서비스 외 2개 항목 \\
\hline & 단지관리서비스 & 단지통합관리서비스 외 3 개 항목 \\
\hline & U-아티팩트서비스 & $\begin{array}{l}\text { 건축외관디지털조명서비스 외 } 5 \text { 개 } \\
\text { 항목 }\end{array}$ \\
\hline & U-테마거리서비스 & 첨단거리기술체험서비스 외 1 개 항목 \\
\hline
\end{tabular}


위의 <표 $1>$ 은 현재 각 기관 단체별로 제공하고 있는 기본적인 형태라고 할 수 있다. <표 1>에서 나타나듯 제공에 대한 어떠한 기준 없이 목록의 나열로서 제공되는 서비스의 단위는 기존 도시 공 간과 특성이 다른 $\mathrm{u}$-도시생활공간에 대한 특화된 설계기법이 없어 공간과 $\mathrm{u}$-서비스의 부조화가 발 생하거나, 서비스와 기술에 대한 상세 분석 부족 으로 사업성이 부족하거나, 구축비용이 예상대비 증가하여 운영비용을 충당하기 어려운 문제를 야 기 시킨다고 할 수 있으며, 이는 u-City 시장 성장 에 있어서 큰 장애물이 되고 있다.

따라서 본 연구에서는 위와 같이 제공되는 $\mathrm{u}^{-}$서 비스 목록들을 $\mathrm{u}-\mathrm{City}$ 내 각 공간의 특성과 이용 자의 요구에 적합한 $\mathrm{u}^{-}$서비스가 어떠한 것인지, 또 그에 따른 방법은 어떠해야 하는지에 대해서 제안하고자 한다.

\section{3. $\mathrm{u}^{-}$서비스 추출 방법론}

\section{1 배경이론 및 기법 고찰}

\subsection{1 서비스사이언스}

$\mathrm{u}^{-}$서비스 추출 방법론의 배경이론이 되는 서비스 사이언스는 목적, 대상, 방법을 구분하여 “서비스 의 개발, 운영, 개선을 위한 과학적 방법론 및 응 용기술을 연구하는 학제적 학문분야”라고 정의 된 다. 따라서 본 연구에서는 $\mathrm{AHP}$ 와 $\mathrm{QFD}$ 기법을 응 용하여 $\mathrm{u}^{-}$서비스 추출 방법론을 제안하고자 한다.

〈표 2〉Service Science의 특징

\begin{tabular}{c|l}
\hline 구 분 & \multicolumn{1}{c}{ 내용 } \\
\hline \hline Service & $\begin{array}{l}\text { 서비스에 연구 도구나 방법론을 } \\
\text { 이용해 새로운 지식을 창출 }\end{array}$ \\
\hline Science & $\begin{array}{l}\text { 가치를 창출하고 만들어 내는 } \\
\text { 프로세스를 개선 }\end{array}$ \\
Management & $\begin{array}{l}\text { 과학에서 도출된 지식을 활용하여 } \\
\text { 새로운 가치를 생산 }\end{array}$ \\
\hline Eervice
\end{tabular}

\subsubsection{AHP(Analysis Hierarchy Process)}

$\mathrm{AHP}$ 는 의사결정요소들의 속성과 그 측정 척도
가 다양한 다기준 의사결정문제(多基準 意思決定 問題)에 효과적으로 적용되어 의사결정자가 선택할 수 있는 여러 가지 대안들을 체계적으로 순위화를 시키고, 그 가중치(weight)를 비율척도(ratio scale) 로 도출하는 방법을 제안한다.

[표 3] AHP 기법의 쌍대비교 행렬 예시

\begin{tabular}{c|c|c|c|c}
\hline & A1 & A2 & $\cdots$ & An \\
\hline \hline $\mathrm{A} 1$ & $\mathrm{~V} 1 / \mathrm{V} 1$ & $\mathrm{~V} 1 / \mathrm{V} 2$ & $\cdots$ & $\mathrm{V} 1 / \mathrm{Vn}$ \\
\hline $\mathrm{A} 2$ & $\mathrm{~V} 2 / \mathrm{V} 1$ & $\mathrm{~V} 2 / \mathrm{V} 2$ & $\cdots$ & $\mathrm{V} 2 / \mathrm{Vn}$ \\
\hline$\cdots$ & $\cdots$ & $\cdots$ & $\cdots$ & $\cdots$ \\
\hline $\mathrm{An}$ & $\mathrm{Vn} / \mathrm{V} 1$ & $\mathrm{~V} 2 / \mathrm{Vn}$ & $\cdots$ & $\mathrm{Vn} / \mathrm{Vn}$ \\
\hline
\end{tabular}

위의 <표 3>에서 $\mathrm{V} 1 / \mathrm{V} 1$ 은 $\mathrm{A} 1$ 자신에 비교한 것으로 그 값은 1 이다. $\mathrm{V} 1 / \mathrm{V} 2$ 는 $\mathrm{A} 2$ 에 비교한 $\mathrm{A} 1$ 의 심각정도를 나타낸 값이고 $\mathrm{V} 1 / \mathrm{Vn}$ 은 $\mathrm{An}$ 에 비 교한 $\mathrm{A} 1$ 의 쌍대비교 값을 의미한다.

다음으로 전문가 집단이 주관적으로 판단한 요 소간의 심각성이 이행성의 공리를 만족시키면서 얼마나 일관성 있게 응답 하였는가를 알기 위해서 일치성분석이 필요하게 되는데, 일치성 분석의 과 정은 다음과 같다.

첫째, 최대고유치(principal Eigenvalue) $\lambda \max$ 를 구한다.

$$
\begin{aligned}
& {[\mathrm{A}] \mathrm{X}[\mathrm{W}]=[\mathrm{Y}] \text { 이고, }} \\
& (\mathrm{Y} 1 / \mathrm{W} 1+\mathrm{Y} 2 / \mathrm{W} 2+\cdots+\mathrm{Yn} / \mathrm{Wn}) / \mathrm{n}=\lambda \max
\end{aligned}
$$

둘째, $\lambda \max$ 를 이용하여 일치성지수(Consistency Index : CI)를 구한다.

$$
\mathrm{CI}=\lambda \max -n / n-1, \lambda \max \geq n
$$

(단, $\mathrm{n}=$ 행렬의 차원)

여기서 주관적 쌍대비교가 임의적으로 이루어질 때 발생할 수 있는 값인 일치성비율 $(\mathrm{CR})$ 을 얻게 된 다. 응답자들이 쌍대비교에서 완전히 일치되게 응 
답할 것으로 기대하지는 않지만, 통상 $\mathrm{CR}$ 이 $10 \%$ (0.1)이하이면 양호하게 응답한 것으로 간주된다.

\subsubsection{QFD(Quality Function Deployment)}

품질기능전개라고도 불리는 $\mathrm{QFD}$ (Quality Function Deployment)는 1966년부터 일본의 Akao(1986) 에 의해 제안, 시행되어 온 것으로, 1972년 미츠비 시 중공업 고베 조선소에 의한 품질표로 제안된 후 점차적으로 발전되어 그 중요성이 밝혀졌으며, 「품질기능전개」라는 저서가 발간된 다음 실제 활 용사례가 보고되었다.

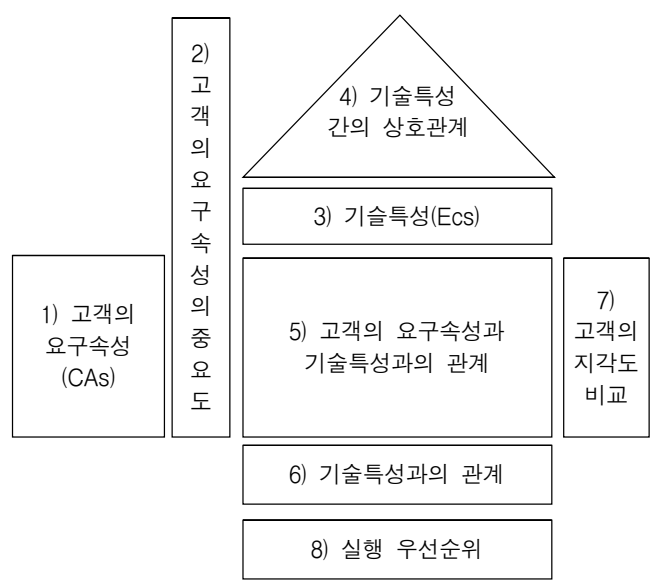

[그림 4] QFD의 구조도(HoQ : House of Quality)

통상적으로 $\mathrm{QFD}$ 의 구조는 [그림 4]와 같이 총 8 단계의 절차를 거치게 되며, 본 연구에서는 8 단 계 중 6 가지 항목을 활용하며, 그에 대한 내용은 다음과 같다.

첫째, 고객의 요구속성(Customer Attributes)은 대상을 정의하고, 대상의 요구속성을 수집 및 분 류하는 단계이다.

둘째, 고객의 요구속성의 중요도는 제시된 요구 속성 간의 상대적 중요도를 표시한다.

셋째, 기술특성(Engineering Characteristics)은 대상의 요구속성을 구체적으로 어떻게(How) 구현 할 것인가를 결정하기 우해 서비스 제공자는 고객
의 요구속성을 기술특성으로 변환해야하는 것이다. 넷째, 고객의 요구속성과 기술특성 간의 상관관 계는 두 가지 요소 간의 연관성을 나타내며, 일반 적으로 기술특성과 고객 요구속성의 상관관계에 대한 파악은 서비스가 제대로 디자인되었는지 점 검할 수 있는 부분이라 할 수 있다.

다섯째, 기술특성 값은 $\mathrm{HoQ}$ 의 지하실에 위치하 며 기술특성 값의 산출과정은 다음과 같다.

$$
\text { 가중치 합 } W_{j}=\sum_{i=1}^{m} D_{i} R_{i j}
$$

* 고객의 요구속성의 상대적 중요도,

$D_{i}, i=1 . \cdots, \mathrm{m}$

* 요구속성과 기술특성 간의 상관관계의 강도,

$$
R_{i j}, i=1 . \cdots, \mathrm{m} j=1, \cdots, \mathrm{n}
$$

여섯째, 실행우선순위는 $\mathrm{HoQ}$ 의 가장 아래 부분 에 해당하며 기술특성의 가중치 합이 높을수록 실 행우선순위가 높다.

이러하듯 $\mathrm{QFD}$ 의 기본적인 프로세스는 총 8가지 의 단계로 이루어지고 있다. 하지만 그 용도와 대 상에 따라서 변형이 가능한 형태로 템플릿을 제공 하고 있다[21].

\section{$3.2 \mathrm{u}$-서비스 추출 방법론의 제안}

본 연구는 앞서 고찰한 바와 같이 $\mathrm{u}^{-}$서비스의 공 급을 대상시민들의 인문적, 사회적, 과학적 분석을 통하여 $\mathrm{u}^{-}$서비스의 제공이 이루어져야 한다는 인

\begin{tabular}{|c|c|}
\hline 단계 & 주요 Activity \\
\hline $\begin{array}{l}\text { 1. 서비스 } \\
\text { 식별 }\end{array}$ & $\begin{array}{l}\text { - } \mathrm{u}^{-} \text {서비스 사용자의 요구사항 예측 } \\
\text { 。 기존 } \mathrm{u}^{-} \text {서비스 분석 } \\
\text { 。 사용가능한 Technology 분석 }\end{array}$ \\
\hline $\begin{array}{l}\text { 2. 서비스 } \\
\text { 추출 }\end{array}$ & $\begin{array}{l}\text { } \mathrm{u}^{-} \text {서비스 특성 도출 } \\
\text { 적합한 } \mathrm{u}-\text { 서비스 선택 }\end{array}$ \\
\hline $\begin{array}{l}\text { 3. 서비스 } \\
\text { 적용 }\end{array}$ & $\begin{array}{l}\text { 추출된 서비스의 적용 } \\
\text { - Segmentation, Targeting, Positioning }\end{array}$ \\
\hline
\end{tabular}

[표 4] $\mathrm{u}$-서비스 디자인 방법론의 단계별 정의 
식과 이에 대한 체계적인 방법론의 필요성이 대두 되는 상황에서 $\mathrm{u}^{-}$서비스 추출 방법론을 제안하고 자 한다.

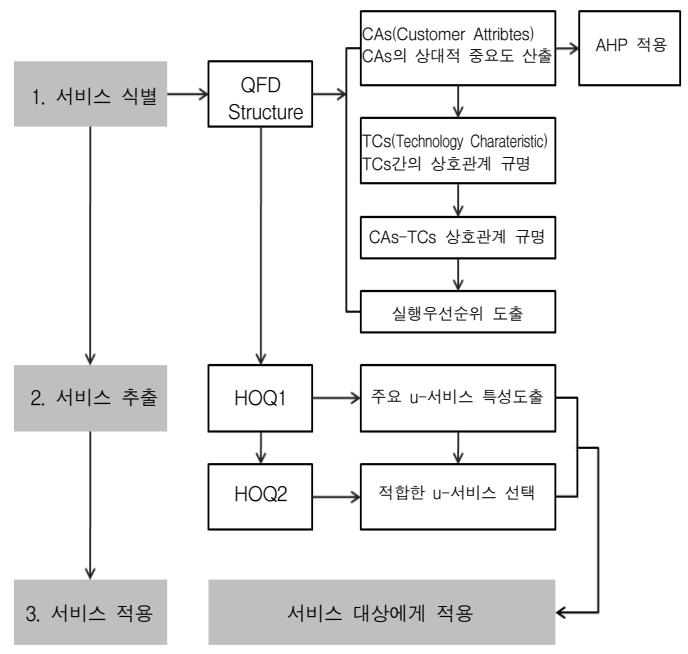

[그림 5] u-서비스 디자인 방법론의 프로세스

본 연구에서 제시하고자 하는 $\mathrm{u}^{-}$서비스 추출 방 법론은 앞서 고찰한 서비스사이언스 기법인 $\mathrm{AHP}$ 와 $\mathrm{QFD}$ 기법을 활용하여 $\mathrm{u}^{-}$서비스 사용자의 요구 사항을 예측하고 그것을 기준으로 기존의 $\mathrm{u}^{-}$서비스 와 앞으로 개발될 $\mathrm{u}^{-}$서비스들의 적합성 판단을 통 해 적합한 $\mathrm{u}-$ 서비스를 제공하는데 목적이 있으며, 그 과정은 [그림 5]에 보듯 다음 3단계를 거친다.

첫째, 서비스 식별단계에서는 사용자의 요구사항 을 예측하기위하여 선행연구문헌 고찰을 통하여 주 공간의 사용자 요구속성 항목을 도출하고, $\mathrm{AHP}$ 기 법의 쌍대비교를 활용하여 $\mathrm{u}-$ 서비스 사용자의 요구 사항을 예측한다.

둘째, 서비스 추출 단계에서는 식별 단계에서 정 의되어지는 $\mathrm{u}^{-}$서비스 사용자 요구속성의 항목들 과 기존의 $\mathrm{u}^{-}$서비스를 $\mathrm{QFD}$ 기법을 사용하여 주거 공간에 적합한 $\mathrm{u}^{-}$서비스를 선택할 수 있는 판단 기 준을 마련한다.

셋째, 서비스 적용 단계에서는 추출된 서비스들의 우선순위를 정하여 가장 높은 수치를 나타내는 항
목들을 공간에 적용하는 과정을 거치게 된다.

$\mathrm{u}$-서비스 추출 방법론은 $\mathrm{QFD}$ 기법의 프로세스 를 적용하였으며, $\mathrm{QFD}$ 기법의 핵심이 되는 사용 자의 요구속성 항목을 도출하는 과정에서 $\mathrm{AHP}$ 기 법을 적용하게 된다.

\section{4. $\mathrm{u}^{-}$서비스 추출 방법론의 적용}

\section{$4.1 \mathrm{U}$-주거공간 사용자 요구속성의 중요도}

\subsection{1 u-주거공간 사용자의 요구속성 도출}

$\mathrm{u}^{-}$주거공간 사용자의 일반적인 요구속성은 현 재 추진되고 있는 $\mathrm{u}-\mathrm{City}$ 내 존재하는 주거공간의 일반적인 요구속성이라 할 수 있다. 하지만 추진 중인 경우가 대부분이며, 아직 그 서비스 대상을 구체적으로 규명하기가 쉽지 않기 때문에 이에 대 한 사용자의 서비스 요구속성을 정량적으로 추출 하는 것은 한계를 가진다. 따라서 본 연구에서는 주거요구, 주거만족도, 미래주거 변화양상 등의 문 헌고찰을 통하여 거주민의 사용자 요구속성을 도 출하였다[1].

<표 5>에서 나타나듯 선행연구사례의 검토결과 분석된 항목들은 $\mathrm{u}$-주거공간에 적합한 서비스를 추출하기 위하여 거주자의 주거요구, 입주 결정시 우선고려사항, 반영 희망요소의 3가지 특성으로 분류하고, $\mathrm{u}^{-}$서비스 수요조사 자료를 근거로 분석 하여 물리적/서비스적 요소와 서비스적 요소에 해 당하는 항목들을 정리함으로서 이를 $\mathrm{u}$-주거공간 사용자의 요구속성으로 변환하였다.

\subsection{2 u-주거공간 사용자 요구속성의 중요도 산출 \\ $\mathrm{u}^{-}$주거공간 사용자 요구속성의 중요도를 측정} 하기 위하여 $\mathrm{AHP}$ 기법과 툴을 적용한 쌍대비교를 통하여 중요도의 값을 측정하였으며, $\mathrm{AHP}$ 툴을 적용한 결과는 [그림 6]과 같다.

측정결과에서 일관성 지수(Consistency Index, $\mathrm{AHP}$ 분석과정에서 일치성 지수는 비교수행자가 얼 
〈표 5〉u-주거공간 사용자의 요구속성

\begin{tabular}{|c|c|c|}
\hline 구 분 & 관련 항목 & $\mathrm{u}$-주거공간 사용자의 요구속성 \\
\hline \multirow{5}{*}{$\begin{array}{l}\text { 물 } \\
\text { 리 } \\
\text { 적 }\end{array}$} & 비즈니스 센터 & 업무에 대한 지원 \\
\hline & $\begin{array}{l}\text { 지하철, 버스 등 } \\
\text { 대중교통이 편리 }\end{array}$ & 교통관련 정보 및 콘텐츠의 제공 \\
\hline & $\begin{array}{l}\text { 주변 } \\
\text { 문화시설과의 거리 }\end{array}$ & 문화관련 정보 및 콘텐츠의 제공 \\
\hline & 교육환경이 중요 & 교육 정보 및 콘텐츠의 제공 \\
\hline & $\begin{array}{l}\text { 세 대프라이버시가 } \\
\text { 중요 }\end{array}$ & 세대별 프라이버시 시스템의 제공 \\
\hline \multirow{10}{*}{$\begin{array}{l}\text { / } \\
\text { 서 } \\
\text { 비 } \\
\text { 스 } \\
\text { 적 } \\
\text { 요 } \\
\text { 소 }\end{array}$} & 주변행정, 업무시설 & 업무에 대한 지원 \\
\hline & 자녀의 교육환경 & 교육 정보 및 콘텐츠의 제공 \\
\hline & 주변 문화시설 & 문화관련 정보 및 콘텐츠의 제공 \\
\hline & 교통의 편리 & 교통관련 정보 및 콘텐츠의 제공 \\
\hline & 실내청정시스템 & 실내 환경조절 시스템의 제공 \\
\hline & 홈 오토메이션 & 주거공간의 자동화 시스템 제공 \\
\hline & 가변형 주거시스템 & 주거공간의 가변 시스템 제공 \\
\hline & 교육시설 & 교육 정보 및 콘텐츠의 제공 \\
\hline & 문화시설 & 문화관련 정보 및 콘텐츠의 제공 \\
\hline & $\begin{array}{l}\text { 각 세대의 관리비 } \\
\text { 절감 문제 }\end{array}$ & 관리비 절감 시스템의 제공 \\
\hline \multirow{10}{*}{$\begin{array}{l}\text { 서 } \\
\text { 비 } \\
\text { 스 } \\
\text { 적 } \\
\text { 요 } \\
\text { 소 }\end{array}$} & $\begin{array}{l}\text { 보안시설 및 } \\
\text { 방범시스템 }\end{array}$ & 보안 및 방범시스템의 제공 \\
\hline & $\begin{array}{l}\text { 종합유선, 위성방송 } \\
\text { 등 첨단네트워크 }\end{array}$ & 다양한 네트워크 콘텐츠의 제공 \\
\hline & $\begin{array}{l}\text { 이웃과 서로 알고 } \\
\text { 지내는 것 }\end{array}$ & 커뮤니티의 제공 \\
\hline & 첨단 보안시스템 & 보안 및 방범시스템의 제공 \\
\hline & 공동체프로그램 & 커뮤니티의 제공 \\
\hline & 호텔식 서비스 & 도우미 서비스의 지원 \\
\hline & 사무, 비서업무제공 & 업무에 대한 지원 \\
\hline & $\begin{array}{l}\text { 여가활동 } \\
\text { 무료이용 서비스 }\end{array}$ & 여가활동에 대한 지원 \\
\hline & $\begin{array}{l}\text { 보안경비요원 } \\
\text { 출동 서비스 }\end{array}$ & 응급상황에 대한 지원 \\
\hline & 가사도움 서비스 & 도우미 서비스의 지원 \\
\hline
\end{tabular}

만큼의 일관성을 가지고 결과 구했는가를 보여주 는 지표이다. 해당 factor의 전문성이 높을수록, 일 치성지수는 낮게 나오게 된다. 통상 일치성지수가 0.1 이상이면 결과를 신뢰할 수 없다고 본다)는 0.0464 로 신뢰할 수 있다고 판단되는 결과 값을 얻 을 수 있었으며, $\mathrm{u}^{-}$주거공간 사용자 요구속성 및 중요도 분석결과는 <표 $6>$ 와 같으며, 분석결과를 보면 $\mathrm{u}^{-}$주거공간의 사용자들은 “교육 정보 및 콘

\section{〈표 6〉u-주거공간 사용자 요구속성의 중요도}

\begin{tabular}{|c|c|c|c|}
\hline $\begin{array}{l}\text { 서비스 } \\
\text { 구분 }\end{array}$ & $\mathrm{u}$-주거공간 사용자의 요구속성 & 구 분 & $\begin{array}{l}\text { 상대적 } \\
\text { 관련도 }\end{array}$ \\
\hline \multirow{6}{*}{$\begin{array}{l}\text { 물 } \\
\text { 리 } \\
\text { 적 } \\
/ \\
\text { 서 } \\
\text { 비 } \\
\text { 스 } \\
\text { 적 }\end{array}$} & 업무에 대한 지원 & Factor 1 & 0.020 \\
\hline & 교통관련 정보 및 콘텐츠의 제공 & Factor 2 & 0.061 \\
\hline & 문화관련 정보 및 콘텐츠의 제공 & Factor 3 & 0.033 \\
\hline & 교육 정보 및 콘텐츠의 제공 & Factor 4 & 0.159 \\
\hline & 세대별 프라이버시 시스템의 제공 & Factor 5 & 0.079 \\
\hline & 실내 환경조절 시스템의 제공 & Factor 6 & 0.045 \\
\hline \multirow{3}{*}{$\begin{array}{l}\text { 요 } \\
\text { 소 }\end{array}$} & 주거공간의 자동화 시스템 제공 & Factor 7 & 0.041 \\
\hline & 주거공간의 가변 시스템 제공 & Factor 8 & 0.073 \\
\hline & 관리비 절감 시스템의 제공 & Factor 9 & 0.079 \\
\hline \multirow{4}{*}{$\begin{array}{l}\text { 서 } \\
\text { 비 } \\
\text { 스 } \\
\text { 적 }\end{array}$} & 보안 및 방범시스템의 제공 & Factor 10 & 0.143 \\
\hline & 다양한 네트워크 콘텐츠의 제공 & Factor 11 & 0.022 \\
\hline & 도우미 서비스의 지원 & Factor 12 & 0.025 \\
\hline & 커뮤니티의 제공 & Factor 13 & 0.052 \\
\hline \multirow{2}{*}{$\begin{array}{l}\text { 요 } \\
\text { 소 }\end{array}$} & 여가활동에 대한 지원 & Factor 14 & 0.018 \\
\hline & 응급상황에 대한 지원 & Factor 15 & 0.150 \\
\hline
\end{tabular}

(1) 가중치 산정 결과

\begin{tabular}{|l|l|}
\hline Consistency Index & 0.0464 \\
\hline
\end{tabular}

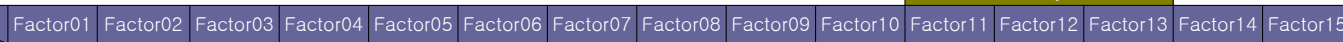
\begin{tabular}{|l|l|l|l|l|l|l|l|l|l|l|l|l|l|l|}
0.020 & 0.061 & 0.033 & 0.159 & 0.079 & 0.045 & 0.041 & 0.073 & 0.079 & 0.143 & 0.022 & 0.025 & 0.052 & 0.018 & 0.150 \\
\hline
\end{tabular}

(2) 비교 행렬

\begin{tabular}{|c|c|c|c|c|c|c|c|c|c|c|c|c|c|c|c|}
\hline & Factor01 & Factor02 & Factor03 & Factor04 & Factor05 & Factor06 & Factor07 & Factor08 & Factor09 & Factor10 & Factor11 & Factor 12 & Factor13 & Factor14 & Factor15 \\
\hline Factor01 & 1 & 0.33 & 0.5 & 0.2 & 0.33 & 0.5 & 0.33 & 0.25 & 0.25 & 0.25 & 1 & 0.5 & 0.33 & 1 & 0.2 \\
\hline$\overline{\text { Factor02 }}$ & 3.03 & 1 & 3 & 0.33 & 0.5 & 1 & 2 & 1 & 0.33 & 0.25 & 3 & 3 & 2 & 4 & 0.33 \\
\hline Factor03 & 2 & 0.33 & 1 & 0.25 & 0.33 & 0.5 & 1 & 0.33 & 0.5 & 0.25 & 2 & 2 & 0.5 & 2 & 0.25 \\
\hline Factor04 & 5 & 3.03 & 4 & 1 & 3 & 4 & 4 & 3 & 3 & 2 & 5 & 5 & 2 & 5 & 1 \\
\hline Factor05 & 3.03 & 2 & 3.03 & 0.33 & 1 & 2 & 2 & 1 & 1 & 0.5 & 4 & 3 & 2 & 4 & 0.5 \\
\hline Factor06 & 2 & 1 & 2 & 0.25 & 0.5 & 1 & 1 & 0.5 & 0.5 & 0.33 & 2 & 2 & 1 & 3 & 0.25 \\
\hline Factor07 & 3.03 & 0.5 & 1 & 0.25 & 0.5 & 1 & 1 & 0.5 & 0.33 & 0.25 & 3 & 2 & 1 & 2 & 0.33 \\
\hline Factor08 & 4 & 1 & 3.03 & 0.33 & 1 & 2 & 2 & 1 & 1 & 0.33 & 4 & 4 & 1 & 5 & 0.33 \\
\hline Factor09 & 4 & 3.03 & 2 & 0.33 & 1 & 2 & 3.03 & 1 & 1 & 0.33 & 3 & 4 & 1 & 4 & 0.25 \\
\hline Factor 10 & 4 & 4 & 4 & 0.5 & 2 & 3.03 & 4 & 3.03 & 3.03 & 1 & 5 & 4 & 3 & 5 & 1 \\
\hline$\overline{\text { Factor } 11}$ & 1 & 0.33 & 0.5 & 0.2 & 0.25 & 0.5 & 0.33 & 0.25 & 0.33 & 0.2 & 1 & 1 & 0.5 & 2 & 0.2 \\
\hline Factor 12 & 2 & 0.33 & 0.5 & 0.2 & 0.33 & 0.5 & 0.5 & 0.25 & 0.25 & 0.25 & 1 & 1 & 0.5 & 2 & 0.25 \\
\hline Factor 13 & 3.03 & 0.5 & 2 & 0.5 & 0.5 & 1 & 1 & 1 & 1 & 0.33 & 2 & 2 & 1 & 3 & 0.33 \\
\hline Factor 14 & 1 & 0.25 & 0.5 & 0.2 & 0.25 & 0.33 & 0.5 & 0.2 & 0.25 & 0.2 & 0.5 & 0.5 & 0.33 & 1 & 0.2 \\
\hline Factor 15 & 5 & 3.03 & 4 & 1 & 2 & 4 & 3.03 & 3.03 & 4 & 1 & 5 & 4 & 3.03 & 5 & 1 \\
\hline
\end{tabular}

[그림 6] AHP 툴 결과 이미지 
텐츠의 제공”, “보안 및 방범시스템의 제공”, “응 급상황에 대한 지원"의 차원에 대한 항목을 중요 하게 인식하고 있다. 또한 '세대별 프라이버시 시 스템의 제공', '관리비 절감 시스템의 제공', '주거 공간의 가변 시스템 제공' 등이 거주자가 요청하 는 중요 $\mathrm{u}^{-}$서비스 항목으로 나타난다.

\section{$4.3 \mathrm{u}$-주거공간 사용자 요구속성과 서비스의 상관관계}

$\mathrm{u}^{-}$주거공간 사용자 요구속성의 중요도에 따른 228 개 단위서비스를 설문조사를 통하여 $\mathrm{QFD}$ 과정 에 대입하여 상관관계를 규명하는 단계로 설문을 통하여 진행되었다.

설문 대상은 U-city 관련 전문가 10 명, 도시계 획 - 건축 - 디자인을 전공으로 하는 학생 및 교수 40 명을 대상으로 진행하였다. 또한 관련 연구의 내 용을 참조[4]하여 강도에 따라 강(9점), 중간(3점), 약(1점)으로 3 단계로 구분하였으며, 설문에서 높은 결과의 비율의 것을 점수로 기준으로 반영하였다. <표 7>는 본 연구의 $\mathrm{QFD}$ 과정의 $\mathrm{HoQ}$ 일부로서 228 개 단위서비스 항목의 상위 10 개를 편집한 결 과이다.

\section{$4.4 \mathrm{u}$-주거공간 $\mathrm{U}$-서비스의 추출 및 우선순위}

본 연구에서 진행한 방법론의 $\mathrm{HoQ}$ 데이터는 $\mathrm{u}^{-}$ 주거공간 사용자 요구속성의 중요도 값과

서비스의 상관관계의 강도를 곱하여, 이 값을 가중치 합으로 산출하게 된다.

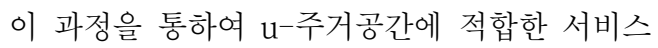
의 우선순위를 정하게 되며, 우선순위가 높을수록 적합한 서비스라고 판단할 수 있다. 본 연구에서 는 상위 10 개 서비스를 선택적으로 도출하였으며, 그 내용은 <표 8>과 같다.

\section{5. 결 론}

현재 추진되고 있는 $\mathrm{u}-\mathrm{City}$ 건설계획은 시민들 이 제공받아야 할 $\mathrm{u}-$ 서비스와 공급자인 도시정부 가 제공해야할 $\mathrm{u}^{-}$서비스가 무엇인가에 대한 논의 가 부족한 가운데 공급자위주의 $\mathrm{u}^{-}$서비스를 제공 하는 것에서 문제점이 발생한다. 즉, $\mathrm{u}-\mathrm{City} \mathrm{u} \mathrm{u}^{-}$서 비스를 제공하는 지방자치단체와 같은 공급자의 입장에서 기술제공에 관하여 대부분의 연구가 진 행되는 문제점으로 인해, $\mathrm{u}$-서비스를 이용하는 시 민들의 이용현황과 활용범위를 대상으로 한 $\mathrm{u}^{-}$서

〈표 7〉u-주거공간 사용자의 요구속성과 서비스의 상관관계

\begin{tabular}{|c|c|c|c|c|c|c|c|c|c|c|c|c|c|c|c|}
\hline $\begin{array}{ll}288 \text { 개 } & \text { 요구 } \\
\text { 단위서비스 } & \text { 속성 }\end{array}$ & $\begin{array}{l}F \\
1\end{array}$ & $\begin{array}{l}F \\
2\end{array}$ & $\begin{array}{l}F \\
3\end{array}$ & $\begin{array}{l}\mathrm{F} \\
4\end{array}$ & $\begin{array}{l}F \\
5\end{array}$ & $\begin{array}{l}F \\
6\end{array}$ & $\begin{array}{l}F \\
7\end{array}$ & $\begin{array}{l}F \\
8\end{array}$ & $\begin{array}{l}F \\
9\end{array}$ & $\begin{array}{c}\mathrm{F} \\
10\end{array}$ & $\begin{array}{c}\mathrm{F} \\
11\end{array}$ & $\begin{array}{c}F \\
12\end{array}$ & $\begin{array}{c}F \\
13\end{array}$ & $\begin{array}{c}\mathrm{F} \\
14\end{array}$ & $\begin{array}{c}F \\
15\end{array}$ \\
\hline 위급알림 서비스 & & & & & & & & & & 9 & & 1 & & & 9 \\
\hline 스쿨존 서비스 & & & & 3 & & & & & & 9 & & 1 & & & 3 \\
\hline 가정방범방재 서비스 & & & & & 9 & & & & & 9 & & 3 & & & 1 \\
\hline 공공지역 안전감시 서비스 & & & & & & & & & & 3 & 1 & 3 & & & 9 \\
\hline 응급구조 서비스 & & & & & & & & & & 3 & & 3 & & & 9 \\
\hline 온라인교육 서비스 & & & & 9 & & & 3 & & & & 3 & 3 & 1 & & \\
\hline \multicolumn{16}{|c|}{$\vdots$} \\
\hline u-놀이터 서비스 & & & & 3 & & & & & & 3 & & 1 & 3 & 3 & 3 \\
\hline 노약자 안전생활 모니터링 서비스 & & & & & & & & & & & & & 3 & & 9 \\
\hline 홈오토메이션 서비스 & & & & & & 3 & 9 & 9 & 3 & & 1 & 1 & & 3 & \\
\hline 치매노인/미아방지서비스 & & & & & 1 & & & & & 9 & & 3 & 1 & & \\
\hline
\end{tabular}


〈표 8〉u-주거공간에 적합한 서비스 도출

\begin{tabular}{|c|c|c|c|c|}
\hline 서비스명 & 서비스정의 & $\begin{array}{c}\text { 우선순위 } \\
\text { 중요도 }\end{array}$ & \multicolumn{2}{|c|}{$\mathrm{u}$-주거공간 서비스 내용 } \\
\hline \multirow{3}{*}{$\begin{array}{l}\text { 위급알림 } \\
\text { 서비스 }\end{array}$} & \multirow{3}{*}{$\begin{array}{l}\text { 。 시민이 위급상황 시 가까이 있는 지능형가로등 또는 휴대형 단말을 통해 위급 } \\
\text { 상황을 즉각 운영센터로 알리고 센터에서는 시민의-위치와 상황을 CCTV를 } \\
\text { 통해 바로 파악하여 해당지역에 경고상황을 발생시키거나 출동하는 서비스 } \\
\text { 아로등 또는 CCTV 설치공간, 지능형 Pole에 도움벨이나 상황감지센서를 부착 } \\
\text { 위급 시 자신의 위치 및 상황을 } 119 \text { 나 관할경찰서, 지정기관에 자동 통보 }\end{array}$} & \multirow{3}{*}{$\begin{array}{l}4.84 \% \\
(1)\end{array}$} & 범위 & 단지 내 가로 \\
\hline & & & 형태 & $\begin{array}{l}\text { 지능형 가로등, 지능형 pole, } \\
\text { CCTV }\end{array}$ \\
\hline & & & Technology & 상황감지센서, 상황인식 \\
\hline \multirow{3}{*}{$\begin{array}{l}\text { 스쿨존 } \\
\text { 서비스 }\end{array}$} & \multirow{3}{*}{$\begin{array}{l}\text { 통학로 주변, 교내 등에 CCTV, 속도감지기를 설치하여 차량과속 등 어린이 } \\
\text { 위협요소를 제거하고 교내 어린이안전을 강화하며 운전자에게는 근처에 있는 } \\
\text { 어린이의 존재유무를 알려주어 안전운전을 유도하는 서비스 } \\
\text { 。통학로 주변, 교내 등에 CCTV와 속도감지기를 설치하여 차량과속방지 및 } \\
\text { 불법 주·정차 등 위협요소를 제거 } \\
\text { 。스쿨존, 주거지역 등 어린이사고 다발예상지역에 DFS 및 RFID 기술을 } \\
\text { 이용하여 어린이 존재유무를 운전자에게 경고 }\end{array}$} & \multirow{3}{*}{$\begin{array}{l}4.07 \% \\
(2)\end{array}$} & 범위 & $\begin{array}{l}\text { 학교 인접 동선상의 가로 및 } \\
\text { 횡단보도 }\end{array}$ \\
\hline & & & 형태 & 지능형 횡단 시스템 \\
\hline & & & Technology & $\begin{array}{l}\mathrm{RFID}, \text { 상황인식, } \\
\text { 속도감지세서, } \\
\text { 실감형미디어콘텐츠 }\end{array}$ \\
\hline \multirow{3}{*}{$\begin{array}{c}\text { 가정방범 } \\
\text { 방재 } \\
\text { 서비스 }\end{array}$} & \multirow{3}{*}{$\begin{array}{l}\text { 。각 가정/소규모 빌딩에 각종 경비용 Device, 화재/누전센서 등을 설치하여 } \\
\text { 이상상황 발생 시 담당기관에서 원격으로 확인 } \\
\text { 。각 가정/소규모빌딩에 각종경비 Device를 설치하여 이상발생시 관제센터에서 } \\
\text { 근접순찰팀을 파견하여 대응하며 부재시 순회 관리하여 재산을 보호함 } \\
\text { 。가스누출, 화재발생, 누전 등의 사고발생시 소방서 등 담당기관에서 원격으로 } \\
\text { 이를 인식하고 신속하게 대처함 }\end{array}$} & \multirow{3}{*}{$\begin{array}{l}4.04 \% \\
(3)\end{array}$} & 범위 & 주거출입구, 단위 세대출입구 \\
\hline & & & 형태 & $\begin{array}{l}\mathrm{RFID} \text { 출입보안 시스템, } \\
\text { 화재누전방지 시스템, 경비 } \\
\text { 시스템 }\end{array}$ \\
\hline & & & Technology & $\begin{array}{l}\text { RFID 보안기술, 각종 경비 } \\
\text { Device }\end{array}$ \\
\hline \multirow{3}{*}{$\begin{array}{l}\text { 공공지역 } \\
\text { 안전감시 } \\
\text { 서비스 }\end{array}$} & \multirow{3}{*}{$\begin{array}{l}\text { 。 공공지역의 안전유지를 위해 이상상황을 지능적으로 감지할 수 있는 지능형 } \\
\text { CCTV 및 각종 안전관련 센서를 설치하여 이상상황 발생 시 해당지역에 } \\
\text { 경고방송 등을 하고 신속하게 출동하는 서비스 } \\
\text { ㅇㄱㅇ공지역의 관리 및 범죄예방을 위해 지능형CCTV 및 센서를 활용한 감시 } \\
\text { 체계구축 } \\
\text { 。범죄 및 사고위험상황에 대한 경고방송 등을 통하여 사고지역내 피해 최소화 }\end{array}$} & \multirow{3}{*}{$\begin{array}{l}3.41 \% \\
(4)\end{array}$} & 범위 & 단지 내 오픈스페이스 \\
\hline & & & 형태 & 지능형 CCTV \\
\hline & & & Technology & 상황감지센서, 상황인식 \\
\hline \multirow{3}{*}{$\begin{array}{l}\text { 응급구조 } \\
\text { 서비스 }\end{array}$} & \multirow{3}{*}{$\begin{array}{l}\text { 。 조난상황 등 구조가 필요한 상황에 시민이 휴대형 단말로 상황을 통보하면 } \\
\text { 해당기관에서 시민의튀치를 실시간으로 파악하여 응급 구자흔 서비스 } \\
\text { - } 119 \text { 나 응급구난 출동기관에 사고나 발병 등을 자동으로 통보하여 언제 어디에 } \\
\text { 서나 응급구난 제공 } \\
\text { - } \mathrm{LBS} \text { 을 이용하여 얻은 위치측위정보를 바탕으로 헬기나 선박 등에서 조난자의 } \\
\text { 위치를 실시간파악과 신속한 구조 }\end{array}$} & \multirow{3}{*}{$\begin{array}{c}3.37 \% \\
(5)\end{array}$} & 범위 & 단지 내 전지역 \\
\hline & & & 형태 & 휴대형 단말기 \\
\hline & & & Technology & LBS, GIS \\
\hline \multirow{3}{*}{$\begin{array}{l}\text { 온라인 } \\
\text { 교육 } \\
\text { 서비스 }\end{array}$} & \multirow{3}{*}{$\begin{array}{l}\text { 。 유무선 방송통신 인프라와 PC, DTV, 휴대폰, PS 등 다양한 단말기를 기반으로 } \\
\text { 언제 어디서나 디지털교육 컨텐츠를 학습하거나 실시간원격강의를 수강할 수 } \\
\text { 있는 서비스 } \\
\text { 아정에서 학습가능한 양방향디스플레이장치, 교육지원 시스템을 이용한 원격강의 } \\
\text { 。생활권내 특정분야에 재능있는 자가 강사가 되어 개인방송으로 주변학생 또는 } \\
\text { 주민들의 교육/학습활동 지원 }\end{array}$} & \multirow{3}{*}{$\begin{array}{c}3.41 \% \\
(6)\end{array}$} & 범위 & $\begin{array}{l}\text { 주거 내 외부공간, 단위세대 } \\
\text { 내 서비스 공간 }\end{array}$ \\
\hline & & & 형태 & $\begin{array}{l}\text { 세대권내 커뮤니티 강사에게 } \\
\text { 공간제공, DTV }\end{array}$ \\
\hline & & & Technology & 양방향 디스플레이, DTV \\
\hline \multirow{3}{*}{$\begin{array}{l}\mathrm{u} \text {-놀이터 } \\
\text { 서비스 }\end{array}$} & \multirow{3}{*}{$\begin{array}{l}\text { 。 다양한 유비쿼터스기술과 기기를 이용하여 어린이들이 보다 흥미롭고 교육적 } \\
\text { 효과 또한 제공할 수 있는 첨단놀이터 구축 } \\
\text { 。 U-기술, LED 조명, 멀티미디어, 센서 등 첨단 IT 기술을 적용한 어린이놀이터 } \\
\text { 。 U-서비스 체혐, 놀이, 게임, 교육을 통해 흥미있는 공간 연출 } \\
\text { 。 디지털징검다리, 놀이기구, 사이버투어, 암벽놀이, 디지털놀이판, 멜로디의자 등 } \\
\text { 설치 }\end{array}$} & \multirow{3}{*}{$\begin{array}{c}3.18 \% \\
(7)\end{array}$} & 범위 & 단지 내 놀이터 \\
\hline & & & 형태 & $\begin{array}{l}\text { IT를 활용한 } \\
\text { 놀이시설(체혐학습 }\end{array}$ \\
\hline & & & Technology & $\begin{array}{l}\mathrm{LED} \text { 조명, 상황인식, 증강 } \\
\text { 현실, 실감형미디어콘텐츠 }\end{array}$ \\
\hline \multirow{3}{*}{\begin{tabular}{l|} 
노약자 \\
안전 생환 \\
모니터링 \\
서비스
\end{tabular}} & \multirow{3}{*}{$\begin{array}{l}\text { 옹약자가 착용한 활동센서와 생활공간의 동작감지센서, 응급호출 장비를 통해 } \\
\text { 노약자의 낙상, 무동작을 비롯한 각종 응급상황발생시 응급상황 정보가 } \\
\text { 원격지에서 실시간 모니터링되어 신속한 구급구조 서비스를 제공하는 서비스 } \\
\text { 이상상황 발생 시 보호자, 구급구조기관, 가장 근접한 자원봉사자 등에 자동 } \\
\text { 통보 }\end{array}$} & \multirow{3}{*}{$\begin{array}{c}2.89 \% \\
(8)\end{array}$} & 범위 & 단위세대 내부 \\
\hline & & & 형태 & $\begin{array}{l}\text { 센서노드, } \\
\text { Moving wall pad }\end{array}$ \\
\hline & & & Technology & 상황인식, 센싱 \\
\hline \multirow{3}{*}{$\begin{array}{l}\text { 홈 오토 } \\
\text { 메이션 } \\
\text { 서비스 }\end{array}$} & \multirow{3}{*}{$\begin{array}{l}\text { 。홓서버를 통해 세대내부의 조명, 에너지, 환경, 정보가전 및 기타설비 등을 } \\
\text { 통합으로 모니터링/제어하여 관리하고 모바일디바이스와 연동해 원격에서 } \\
\text { 관리를 가능하게 하는 서비스 } \\
\text { 。확ㄱㅇㅇ관리서비스 : 통합공조기 제어, 공기질을 감시해 자동으로 환기 및 } \\
\text { 공기청정기 작동 } \\
\text { 。에너지제어서비스 : 냉난방기기통합 및 원격제어, 생활모드제어(외출, 귀가, } \\
\quad \text { 취침, 기상, 방범) }\end{array}$} & \multirow[b]{3}{*}{$\begin{array}{l}2.74 \% \\
(9)\end{array}$} & 범위 & 단위세대 내 \\
\hline & & & 형태 & 실내환경 자동제어 시스템 \\
\hline & & & Technology & 실내환경 제어센서 \\
\hline \multirow{3}{*}{\begin{tabular}{l|} 
치매노인/ \\
미아방지 \\
서비스
\end{tabular}} & \multirow{3}{*}{$\begin{array}{l}\text { 。 치매노인, 어린이, 장애인 등이 착용한 RFID나 전용단말기를 인식하여 위치를 } \\
\text { 실시간 모니터링하여 지정된 지역을 이탈시 보호자에게 통보하고 LBS와 CCTV } \\
\text { 기반의 위치추적을 통해 구조하여 실종을 방지하는 서비스 } \\
\text { - RFID 팔찌나 목걸이 등의 전용단말기에 노약자의 주소, 보호자연락처, 사진, } \\
\text { 지문 등 신원확인에 필요한 정보를 입력하여 시민/공공기관에서 보호가 필요한 } \\
\text { 노약자 발견 시 긴급상황에 신속대처 }\end{array}$} & \multirow{3}{*}{$\begin{array}{l}2.73 \% \\
(10)\end{array}$} & 범위 & 단지 내 전지역 \\
\hline & & & 형태 & $\mathrm{RFID}$ 카드, 전용단말기 \\
\hline & & & Technology & RFID, LBS, GIS, 상황인식 \\
\hline
\end{tabular}


비스 연구는 부족하였다.

이에 본 연구에서는 적절한 $\mathrm{u}^{-}$서비스 제공을 위 하여 기본이론으로서 서비스사이언스의 기법인 $\mathrm{AHP}$ 와 $\mathrm{QFD}$ 를 응용 및 적용하여 $\mathrm{u}^{-}$서비스 방법 론을 제사하였으며, 그에 대한 결론은 다음과 같다.

첫 번째, 본 연구에서 제시하고 있는 $\mathrm{AHP}$ 와 $\mathrm{QFD}$ 를 통한 방법론에 의하여 기존 제공되는 $\mathrm{u}^{-}$ 서비스 중 사용자와 특정 공간의 성격을 반영한 $\mathrm{u}$-서비스 도출이 가능하며, 이는 차후 $\mathrm{u}$-서비스 도입 시 $\mathrm{u}^{-}$서비스 추출 방법으로 활용된다.

두 번째, 국토해양부에서 제시하는 288 개의 단 위서비스 중 사용자를 고려한 U-주거공간의 서비 스의 추출 결과 위급알림서비스(4.84\%), 스쿨존 서 비스(4.07\%), 가정 방범방재서비스(4.04\%), 공공지 역 안전 감시서비스(3.41\%), 응급구조서비스(3.37\%), 온라인교육서비스(3.41\%), u-놀이터서비스(3.18\%), 노약자 안전생활 모니터링서비스(2.89\%), 홈 오토 메이션서비스(2.74\%), 치매노인/미아방지 서비스 (2.73\%) 순으로 나타나고 있다. 이는 교육과 안전 에 대한 내용으로 차후 $\mathrm{u}$-주거공간 서비스 계획 시 우선적으로 고려해야 할 요소로 판단된다.

세 번째, 288개 단위서비스를 대상으로 주거공 간과 사용자를 고려한 서비스를 도출한 결과 선호 도가 떨어지며, 우선순의 중요도 값이 0으로 나타 나는 서비스가 201개로 나타나고 있으며, 이는 앞 서 언급한 것처럼 공급자 측면만을 고려한 결과라 고 판단된다. 이에 향후 단위 $\mathrm{u}$-서비스 제안에 있 어 공간의 성격에 따른 분류와 사용자에 대한 고 려는 중요한 요소가 될 것이라 판단된다.

본 연구에서 사용된 서비스의 단위가 u-Eco City 사업단에서 지정한 228 개 단위서비스이지만, 향후 에 추가적으로 생성될 수 있는 방대한 $\mathrm{u}^{-}$서비스에 대해서도 본 연구의 $\mathrm{u}$-서비스 추출방법론을 적용 해 활용 할 수 있어, 본 연구에서 시민친화적이며 효율적인 서비스의 제공을 위한 추출 기준이 되는 $\mathrm{u}^{-}$서비스 방법론의 프로토타입을 제안하였다.

현재 많은 $\mathrm{u}-\mathrm{City}$ 건설계획이 추진 중이고, 완 공되는 시점에 있지만 현재까지 $\mathrm{u}^{-}$서비스의 제공
에 대한 체계가 정립되지 않은 상황에서 본 연구 에서 제시한 $\mathrm{u}^{-}$서비스 추출 방법론이 각각 그 대 상과 사용자에 맞게 적용된다면, $\mathrm{u}$-City 내의 다 양한 대상의 인문적, 사회적, 환경적 측면을 고려 한 $\mathrm{u}^{-}$서비스의 제공이 현재보다 훨씬 더 효율적인 측면에서 이루어질 수 있다고 예측한다.

\section{참 고 문 헌}

[1] 박중현, “도심 주상복합 거주자의 주거요구 특 성에 관한 연구”, 아주대학교 학위논문, 2005.

[2] 박진현, "SERVQUAL - SPD 기법을 이용한 군 호텔 서비스 품질 개선방안 연구”, 연세대학 교 학위논문 2006.

[3] 이경인, “서비스사이언스에 관한 통합적 고찰", 서강대학교 학위논문, 2007.

[4] 이세정, "품질기능전개를 이용한 공연장 서비 스 품질 측정에 관한 연구”, 성균관대학교 학 위논문, 2008.

[5] 이정수 외 2인, "주거단지 내 $\mathrm{u}^{-}$서비스 우선순 위에 관한연구”, ‘대한건축학회지」, 제 12 권, 제3호(2010).

[6] 황규하, "u-City 현황 및 서비스 모델 분류체 계에 관한 연구”, 연세대학교 학위논문, 2007

[7] 허효성, "주거단지 계획에 있어서 계획요소로 서 u-City 서비스에 관한 연구”, 성균관대학 교 학위논문, 2007.

[8] 장재호, 엄정섭, "수요-공급자를 통합한 $\mathrm{u}^{-}$서 비스 우선순위 평가모형 개발”, r한국지리정 보학회지」, 제 11 권, 제2호(2008).

[9] 김영환, "u-City Technology를 적용한 주상 복합 주거계획에 관한 연구”, 국민대학교 학위 논문, 2008.

[10] 허경아, "문화 콘텐츠로서 스포츠의 대중화를 위한 STP 마케팅에 대한 연구”, 경남대학교 학위논문, 2008.

[11] 서비스사이언스연구회, 「서비스사이언스」, 2008.

[12] 조용준, 안승주, 장정희, "시민친화형 $\mathrm{u}$-City 
서비스 표준 및 수요조사”, 「한국콘텐츠학회논 문지」, 제10권, 제4호(2009).

[13] 정경석, 문태헌, 허선영, "u-City 서비스 표준 체계 정립과 서비스 분류기준의 설정에 관한 연구”, 「대한국토계획학회지」, 제44권, 제3호 (2009).

[14] 김만택, 유비쿼터스 “도시(u-City) 구현방안에 대한 사례 연구”, 고려대학교 학위논문, 2009.

[15] 지충구, " $\mathrm{u}$-City Technology를 적용한 도심 엔터테인먼트 상업시설의 건축계획에 관한 연 구”, 2009.

[16] 신용석, "서비스 중심의 $\mathrm{u}-\mathrm{City}$ 구축방안 연
구”, 한양대학교 학위논문 2009

[17] 조위덕, 「 $\mathrm{u}^{-}$Service Design, 2009.

[18] 안상준, " $\mathrm{u}$-서비스 특성을 이용한 $\mathrm{u}$-City 유 형별 분류기준 수립에 관한 연구”, 서울시립 대학교 학위논문, 2010.

[19] 박상식, “서비스사이언스 관점에서 본 서비스 모델 구성요소 측정항목에 관한 연구, 중앙대 학교 학위논문", 2010.

[20] 안성화, "서비스사이언스에 기초한 서비스 $\mathrm{SCM}$ 의 성과측정 프레임원크", 한양대학교 학위논 문, 2010.

[21] http://www.qfdonline.com/templates/. 


\section{저 자 소 개}

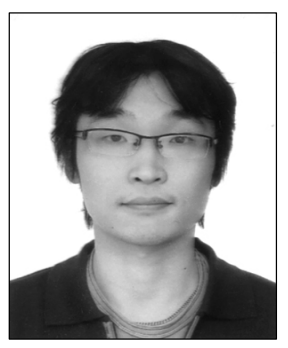

\section{이 행 우 (moonup2001@ nate.com)}

인제대학교 실내디자인과를 졸업하고 국민대 건축디자인 박사과정에 재학 중이다. 또한 지식경제부 지정 지능형 홈 산업화 센터 연구원으로 근무하고 있으며, 주 관심분야는 그린IT, 홈 네트워크, 공간 분석 및 건축에서의 $\mathrm{u}$-서 비스 도출 등이다.

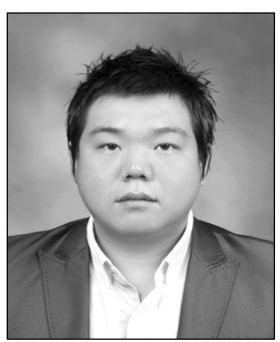

\section{정 진 성 (ronin1983@naver.com)}

신라대학교 건축학부, 국민대학교 테크노디자인전문대학원 건축디자인 석 사과정을 졸업하였으며, 지식경제부 지정 지능형 홈 산업화 센터 연구원으 로 근무하였다. 주 관심분야는 Architectural Technology, Architectural Movement, Archigram 등이다.

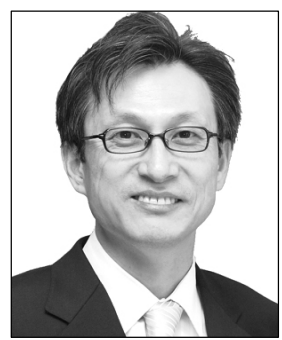

\section{김 용 성 (yongkim@kookmin.ac.kr)}

University of Minnesoata M.Arch., Texas A\&M University Ph.D.를 졸업하 였으며, 현재 국민대학교 건축대학 및 테크노디자인전문대학원 주임교수, 국민대학교 테크노디자인연구소 소장, Aesthetic Architects Inc. 건축가, 지 식경제부 지정 지능형 홈 산업화 지원센터장, 교육과학기술부 BK21 유비쿼 터스 스마트 스페이스 디자인 사업팀장으로 수행중이다. 